\title{
Determinants of Oil Futures Prices
}

\author{
Rebecca Abraham, Charles Harrington \\ Huizenga College of Business, Nova Southeastern University, Fort Lauderdale, FL, USA \\ Email: abraham@nova.edu, charlieh@nova.edu
}

Received 22 May 2016; accepted 7 August 2016; published 10 August 2016

Copyright (C) 2016 by authors and Scientific Research Publishing Inc.

This work is licensed under the Creative Commons Attribution International License (CC BY). http://creativecommons.org/licenses/by/4.0/

(c) (i) Open Access

\section{Abstract}

This study is directed at predicting the determinants of oil futures prices. We evaluate commodity pricing with oil occupying a special position due to highly inelastic demand. Given the sudden fall in oil prices, there is theoretical and practical interest in identifying the determinants of falling oil prices. While the popular press dwells on oversupply in production as the principal determinant of price declines, we examine additional predictors including call option sales and put option purchases along with the Canadian dollar-US dollar exchange rate and news of future oil prices. Intraday call and put options on NYMEX oil futures were examined. Call and put option prices of 1 - 7 month-maturities, along with exchange rates, the supply of oil and news of oil prices were regressed on oil futures prices. A trading strategy was tested based on the thesis that in a period of price declines, options traders seek to profit by selling call options and purchasing put options. While oversupply of oil was the most important determinant of oil prices, trader speculation through put buying and call selling exacerbated the decline in oil prices. Call and put option prices explained oil futures prices for options of 1 - 4 month maturities. The supply of oil was significant in predicting oil futures prices in all future time periods. This was followed by the Canadian dollar-US dollar exchange rate which was significant in predicting oil prices 1, 2, 3 and 6 months into the future. Finally, news of forthcoming events affecting oil prices predicted oil futures prices 3, 4, 5, 6 and 7 months in advance.

\section{Keywords}

Oil Futures, Options, Negative Volume, Price Declines

\section{Introduction}

From 1980-2008, the price of oil moved steadily upwards in response to demand shocks. Demand was price-inelastic, with many consumers and few energy substitutes. Demand inelasticity decreased over time with [1] measuring demand elasticities in the -0.21 to -0.34 range from $1975-1980$ to -0.034 to -0.077 from $2001-2006$. During this early era, there were a few attempts to use options on oil futures to forecast the futures price of oil. 
The underlying reasoning was that option prices contained information that would lead to an accurate forecast of oil futures prices in a frictionless environment ([2]; [3]). With rising oil prices, a trader purchasing call options on oil futures was purchasing the right to purchase oil at a reduced price from that of the market. As oil prices continued to increase, call options on oil futures became more valuable, or the increase in call prices represented the degree of optimism of traders that oil prices would continue to increase. If $c$ is the call price, $F=$ oil futures price, $x=$ strike price of $F$, or reduced purchase price for oil, the Gain to the call buyer upon exercising the option $=F-x-c$ in an era of continually increasing oil prices. This optimism $(F-x-c)$ is a form of informativeness of oil prices contained in options.

However, such optimism reversed with the 2014-2015 decline in oil prices. In that environment, put options on oil futures, or the right to sell oil at a preferred price over the market price increased in value as traders sought to sell oil early at higher prices before prices declined. As oil prices continued to decrease, put options on oil futures rose in value, or the increase in put prices represented the degree of pessimism of traders that oil prices would continue to decrease. If $p$ is the put price, $F=$ oil futures price, $x=$ strike price of $F$, or higher purchase price for oil, the Gain to the put buyer upon exercising the option $=x-F-p$ in an era of continually decreasing oil prices. This pessimism is a form of informativeness of oil prices contained in options. This study quantifies this pessimism and assesses its impact on oil futures prices. In this regard, this study adds to the literature in that existing studies identify the variance of the path of the option as uncertainty in oil futures prices but do not measure such uncertainty [4] or uses adaptations of the Black-Scholes call option pricing model to create call-option estimates without identifying pessimism or optimism in options on oil futures prices [5].

We assume the existence of simultaneous trading in multiple markets in the spirit of [6] and [7]. In other words, trading occurs in both the futures market and the options market. Sellers in the futures market set oil futures prices upon observation of trading behavior in the options market. Suppose a risk-taking options trader wishes to benefit from the continuing reduction in oil prices. The trader purchases $d_{1}$ units of put options with the intent to sell oil at the price $p_{1}$ prevailing in period 1 . Likewise, another trader purchases $d_{2}$ units of put options in the same period, as does yet another trader who buys $d_{3}$ units of put options, so that

$$
d_{1}+d_{2}+d_{3}+\cdots d_{n}=D \text {, the total demand for put options in period } 1 .
$$

The seller in the futures market perceives the demand for put options as the demand for cheap oil, and in turn, reduces the oil futures sales price, $F$, so that $F_{2}<F_{1}$. Traders in the other market, i.e. the futures market, thus pay less for oil due to the speculative trading of options traders via the price reduction undertaken by the market makers in their own futures market. This reduction occurs repeatedly in successive rounds of trading with $F_{4}<$ $F_{3}$ with oil futures prices continuing to decrease to a local minimum. The second derivative of oil futures prices or change in change in oil futures prices, $d^{2} F / d x^{2}=0$, at a local minimum. Oil prices then declined even further during 2015, so that new local minima of oil futures prices were formed successively. Traders continued to buy put options which increased in value in each time period as sellers in the oil futures market continued to adjust prices downwards.

Yet another options trading strategy to capitalize on falling oil futures prices occurs with call selling. Moderately, risk-taking options traders earn the call price for undertaking to deliver a fixed amount of oil futures to call buyers at a fixed price. With falling oil prices, call buyers will never request delivery of oil futures as they will be constrained to pay a higher price for oil futures than they could obtain if they purchased at the market price. For example, if the call options contract required the call buyer to pay $\$ 1.00$ for the privilege of purchasing oil futures at $\$ 70$ per barrel, and the market price of oil futures was $\$ 60.00$ per barrel, call buyers will permit the option to expire and purchase at the market price of $\$ 60.00$ per barrel. Traders selling calls benefit from receiving the call price or the $\$ 1.00$ for the option. Buyers in the oil futures market reduce the price at which they purchase oil futures (oil future bid price) arguing that call sellers benefit from falling oil prices by never having to deliver oil futures and receiving the permanent benefit of earning call premiums.

\section{Hypotheses Development}

\subsection{Options Prices as Predictors of Oil Futures Prices}

By definition, a call option is the right to purchase an asset at the strike price within a certain period of time. In contrast, a put option is the right to sell an asset at the strike price. [6]'s trading model envisioned a single informed trader trading in two markets, i.e. the options market and the stock market. When the financial markets 
send a negative signal, informed traders may sell stock or sell call options or buy put options. We may adapt their theory to the oil futures market and the market for put and call options on oil futures. The oil price declines of 2015 stimulated these traders to either sell oil futures in the oil futures market or sell call options or buy puts in the options on oil futures market. If they opted to sell calls, they were obligated to deliver oil futures to call buyers who were purchasing call futures. In return, they earned a call premium or value of the call option. In each round of trading, the call premium would shrink, ending when call buyers ceased to purchase more oil futures. In the first round of trading, call sellers observe call selling as a signal that demand for call options is about to decline. They lower bid prices on call options. Oil futures sellers interpret the price reduction as reduced demand for oil, and in turn, reduce oil futures prices. The process is repeated in future rounds of trading. So that in the final round, call buyers terminate purchases of call options, call sellers receive no further premiums and trading in call options ends, Alternatively, options traders could buy put options, permitting them to earn higher prices upon sale of the oil futures and buy back at increasingly lower prices. With successive rounds of trading, the put strategy yields gains from oil price declines but loses from higher put prices. In the first round, put sellers observe the increased demand for put options. They increase the purchase price of put options, which sends the message to the oil futures market that the options market perceives greater demand for negative volume or that oil prices will decrease. The oil futures market reduces oil prices. Eventually, the strategy ceases to yield a gain as rising put premiums completely offset any gains from declining oil futures prices. In successive studies, [8] and [9] empirically and theoretically proved the existence of lower bounds for call sell and put purchase trading strategies.

What is the information content embedded in call sale prices and put buy prices? We may derive conclusions from a few existing studies. [10]'s regression of determinants of oil futures prices observed that demand shocks were the most powerful explanatory variable of oil futures prices during 2014-2015, after the commencement of the steep decline in oil prices. They conjectured that such demand shocks arose from the subjective feeling that prices were declining rapidly in the short-term (1 - 4 months). We may extend these findings to the supposition that given the oversupply from OPEC's desire to continue selling at high cartel prices, the US's continued drilling of shale rock to boost production, the restoration of the interrupted Libyan oil production and the sudden resolution of the Iran nuclear agreement which would lift sanctions on Iranian oil sales and release more oil into an oversupplied market. Crude oil's oversupply was compounded in reducing oil prices by news of weakening Chinese demand for oil. Further, there were conversations among NYMEX traders of US drillers suffering layoffs and bankruptcies from reduced drilling stimulating these drillers to increase production to keep workers employed and business in operation. There were other informal conversations occurring daily providing immediate forecasts of the price of oil with short maturities of up to 4 months.

[11]'s regression of oil prices on demand and supply shocks found that both predictable and unanticipated price reductions occurred. \$11 of the predictable decline in crude oil prices reflected the slowing of the global economy due to known reasons such as the economic crisis in Greece, increased European debt, and China’s growth falling below $7.5 \%$ for the first time in a decade. The remaining \$16 emanated from the supply shock of excess production also from anticipated causes including OPEC's failure to reach a production agreement and the rise of non-OPEC production from Canada, Norway and Britain. Further unpredictable declines in oil prices of $\$ 9$ may be attributed to the decrease in precautionary demand. Precautionary demand stems from the storage of oil in centralized facilities to protect the nation's energy supply from fluctuations in the availability of oil. In the US, this inventory of West Texas Intermediate Crude is maintained at Cushing, Oklahoma. The final \$13 of oil price reduction has its source in unanticipated weakening of the global economy including the downward revision of growth forecasts for the United States and Western Europe and countries that depend on the export of commodities whose prices collapsed in early 2015.

Hypothesis 1: Call prices on options with 1 - 4 month maturities significantly explain the variation in oil futures prices.

Hypothesis 2: Put price on options with 1 - 4 month maturities significantly explain the variation in oil futures prices.

As buyers of call options observe trading to capitalize on negative volume, it is conceivable that when they reduce call bid prices, they view put prices to determine the extent to which call prices must be reduced. Likewise, when sellers of put options raise put ask prices, they are likely to observe call prices to guide them on the level to which put ask prices must be increased. Therefore, put prices explain call prices and vice versa.

Hypothesis 3A: Call prices on oil futures explain put prices on oil futures. 
Hypothesis 3B: Put prices on oil futures explain call prices on oil futures.

Call prices are frequently computed using the Black-Scholes model. The Black-Scholes model is the seminal model of estimation of call option prices. It is a partial differential equation which buys and sells the underlying asset (in the case of this paper, oil) to eliminate risk. The Black-Scholes equation specifies that $S$, the price of the underlying asset determines the call price.

$$
c=N\left(d_{1}\right) S-N\left(d_{2}\right) K e^{-r(T-t)}
$$

$C$ is defined as the call price which is directly proportional to the price of the underlying asset. The underlying asset in this case is the oil futures price suggesting that $F$, the oil futures price may predict the call price. $F=S$. Other variables in the equation include $N\left(d_{1}\right)$ and $N\left(d_{2}\right)$, which are probability density functions of the movement of call option prices, $K$, the strike price of the option, $r$, the risk-free rate, $T-t$ is the time to maturity.

Hypothesis 4A: Oil futures prices act as predictors of call prices on oil futures.

The price of a put option on the same underlying asset with identical time to maturity is given by put-call parity as follows.

$$
p=N\left(-d_{2}\right) K e^{-r(T-t)}-N\left(-d_{1}\right) S
$$

Rewriting $S$, the value of the underlying asset as $F$, the oil futures price yields the following put-call parity expression,

$$
p=N\left(-d_{2}\right) K e^{-r(T-t)}-N\left(-d_{1}\right) F
$$

Therefore, the price of a put option on oil futures is directly dependent upon the value of the oil futures, or we may state the hypothesis that oil futures prices act as predictors of put prices on oil futures.

Hypothesis 4B: Oil futures prices act as predictors of put prices on oil futures.

\subsection{The Canadian Dollar to US Dollar Exchange Rate's Impact on Oil Futures Prices}

Oil is denominated in US dollars. [12] presented evidence that the stronger dollar has been linked to decreasing oil prices. The [13] measured US petroleum imports at 9 million barrels per day in 2014, with exports of 4 million barrels of oil. Although the United States is still a net importer to the tune of 5 million barrels per day, the US's energy self-sufficiency was unanticipated ([10]). Much of the output is exported to Canada, which in turn, exports $81 \%$ of its output to the US. The relevant exchange rate becomes the Canadian dollar to US dollar exchange rate. The correlation between the two currency movements has been found to be 0.78 ([13]). The strengthening of the US dollar in 2014-2015 manifested in the weakening of the Canadian dollar to US dollar exchange rate has led to net oil imports from Canada becoming less expensive to US consumers, or reducing the price of oil futures.

Hypothesis 5: The reduction in value of the Canadian dollar to the US dollar has resulted in the decrease in oil futures prices in 2015.

\subsection{Oil Oversupply as a Contributor to Declining Oil Futures Prices}

Oversupply of oil in 2015 originates from two sources. The first source is the excessive production of the OPEC countries. Earlier analysis showed that OPEC's individual members failed to reach an agreement to limit production to boost prices as each individual member became cognizant that exceeding cartel-imposed production quotas resulted in excess profits. OPEC set an informal target of releasing 30 million barrels per day. Libya, Iraq and Nigeria had disruptions to oil production due to political unrest in 2013-2014. [10] maintained that production was restored in all of these locations. Iran negotiated a nuclear agreement with the United States permitting the sale of its oil upon the lifting of sanctions, thereby exacerbating the problems of oversupply. Further, Saudi Arabia, the largest producer, continued to release oil into an oversupplied global market. A single commodity producer, such as Venezuela, relied on oil to support a generous welfare state. The second source of oversupply is the growing importance of non-OPEC production, particularly by the United States. US oil production has emerged through technological advancements in drilling, namely, the extraction of oil from shale rock through fracking. Consequently, the amount of oil produced by the US has remained stable in an environment of price declines due to these technological advancements in the drilling process which reduced the cost of production to the extent that profits could be earned even with reduced prices. The number of rig counts declined from Janu- 
ary-June 2014, then increased.

Hypothesis 6: An increase in supply of oil results in declining oil futures prices.

\subsection{The Impact of News on Oil Prices}

News consists of forecasts of oil prices in terms of supply of oil and demand for oil contained in conversations among oil traders and oil and gas industry professionals. These estimates are subjective in that they are based on anecdotes, stories and visual images that lend color to official forecasts. Theories of investor behavior have determined that such subjective information captures the imagination of investors who are more likely to retain it and make investment decisions based upon it ([14]). Specifically, [15] observed that positive earnings surprises (actual earnings exceeding analysts' forecasts of earnings) were realized for industries with rich, colorful, anecdote-filled histories which complemented statistical reports. [16] observed significant explanation of earnings surprises by pharmaceutical companies who launched new drugs with stories of the firm and its researchers. An example of news of oil prices would be speculation about future interest rates.

Conversations about future interest rates may include news items such as an industry analyst's statement on the impact of an interest rate increase by the Federal Reserve, stories of financial hardship among employees of drilling companies enduring staff reductions and tales of oil companies who were denied loans due to the economic slowdown following an increase in interest rates. News may impact oil prices in the immediate short-term period of 1 - 4 months or beyond the immediate short-term in $>5$ months. As currencies fluctuate daily in value, news of the Canadian dollar to US dollar exchange rate changes that are predictable in the following quarter are likely to be included in a 1 - 2 month forecast of oil prices. Options yield profits upon trading at informed events such as earnings announcements, dividend announcements [6] or merger announcements [7]. The price run up on positive signals for positive earnings surprises, dividends and cash mergers occurs during the few months prior to the event with gains being taken on the event day. Gains from put trading strategies and short selling in response to negative signals are also realized in a few months [7]. Given the short time horizon of oil forecast information embedded in put and call option trades, we may conjecture that option trades will contain 1 - 4 month forecasts of oil futures.

In contrast, predictions of drilling rig counts are likely to achieve fruition in $>4$ months. Given the uncertainty of the successfulness of technological advancements in drilling in reducing the cost of extraction of oil, it may take more than a quarter to gauge if a particular innovation is effective. This time lapse suggests that news will independently influence oil price futures in a time period of 5 - 7 months.

Hypothesis 7: News about oil prices influences oil futures prices realized in 5 - 7 months.

\section{Methodology}

Intraday call option and put prices on oil futures along with daily oil futures prices for 2015 were collected from the New York Mercantile Exchange (NYMEX). A total of 6, 917 observations constituted the final sample. The sample was split into subsamples of options by maturity with options of 1-month, 2-month, 3-month, 4-month, 5-month, 6-month and 7-month maturities. Subsample sizes ranged from 688 observations to 899 observations. Changes in call prices and changes in put prices were included to capture any variance of oil futures prices that was not contained in option prices. Bloomberg's currency data formed the source for intraday Canadian dollar to US dollar exchange rates. The US Energy Administration provided the data on the supply of barrels of oil. Daily news items from the popular press were expressed as a dichotomous variable, coded at 1 and 2 based on the subjective judgement of the researchers of their impact on oil futures prices. Items with limited impact on oil futures prices were coded at level 1. In contrast, items with considerable impact on future oil prices were coded at level 2. Seven separate OLS regressions for options of each maturity were performed using Equation (5) to test hypotheses 1, 2, 5, 6 and 7 .

$$
O F=\alpha+\beta_{1} C P+\beta_{2} D C P+\beta_{3} P P+\beta_{4} D P P+\beta_{5} C A D+\beta_{6} O S+\beta_{7} N O
$$

where

$$
\begin{aligned}
& O F=\text { oil futures price. } \\
& C P=\text { call price. } \\
& D C P=\text { change in call price. } \\
& P P=\text { put price. }
\end{aligned}
$$


$D P P=$ change in put price

$C A D=$ Canadian dollar to US dollar exchange rate.

$O S=$ supply of oil.

$N O=$ news of oil prices.

Hypotheses 3 and 4 were tested using Equation (6) and Equation (7). For options with 1 - 4 month maturities, i.e. the aforementioned subsamples, call prices were regressed on oil futures prices, put option prices, the Canadian dollar to US dollar exchange rate, supply of oil and news of oil prices. This regression was repeated with put prices replacing call prices as the criterion and call prices replacing put prices as a predictor.

$$
\begin{aligned}
& C P=\alpha+\beta_{1} O F+\beta_{2} P P+\beta_{3} C A D+\beta_{4} O S+\beta_{5} N O \\
& P P=\alpha+\beta_{1} O F+\beta_{2} C P+\beta_{3} C A D+\beta_{4} O S+\beta_{5} N O
\end{aligned}
$$

\section{Results}

As shown in Table 1, Hypothesis 1 was supported with call prices explaining a significant amount of the reduction in oil futures prices for 1 - 4 month call options (coefficients ranging from 0.19, $p<0.001$ to $0.92, p<$ 0.001). A reduction in call prices due to call selling is associated with a reduction in oil futures prices. Hypothesis 2 was supported with put option prices significantly influencing oil futures prices for 1 - 4 month put options (coefficients of 0.06 to $1.16, p<0.001$ ). An increase in put prices from put buying is linked to a reduction in oil futures prices. Hypothesis 5 was supported for 1 - 3 month options with the Canadian dollar to US dollar exchange rate's weakening significantly reducing oil futures prices for 1 - 3 month forecasts (coefficients of -0.26 to $0.47, p<0.001$ ). Hypothesis 6 was supported for all time periods with the supply of oil significantly decreasing futures prices (coefficients of $-1.39 \times 10^{-3}, p<0.05$ to $-5.9 \times 10^{-3}, p<0.001$ ). Hypothesis 7 was supported for forecasts of oil prices $3,4,5,6$, and 7 months into the future, with news of oil prices significantly predicting oil futures prices (coefficients $=-0.07$ to $-0.04, p<0.001$ ).

Table 2 shows that oil futures prices were significant predictors of both call and put prices for 1-month and 4-month forecasts (3-month forecasts are not reported as they failed to achieve convergence), supporting Hypotheses 4A and 4B. Call prices significantly predicted put prices for 1, 2 and 4-month options, i.e. reductions in call prices were associated with increases input prices, supporting Hypothesis 3A. Conversely, put prices significantly predicted call prices for 1, 2, and 4-month options with increases input prices being linked to decreases in call prices as indicated by Hypothesis 3B.

\section{Conclusions}

This study has identified the variables that predict the contemporaneous price of oil. These findings are particularly

\begin{tabular}{|c|c|c|c|c|c|c|c|}
\hline Variable & 1-Month & 2-Month & 3-Month & 4-Month & 5-Month & 6-Month & 7-Month \\
\hline Constant & $-0.369^{* * *}$ & $-0.307^{* * *}$ & $-0.191^{* * *}$ & $-0.200^{* * *}$ & $-0.189^{* * *}$ & $-0.222^{* *}$ & $-0.470^{* * *}$ \\
\hline Call Price & $0.21^{* * *}$ & $0.19^{* *}$ & $-0.92^{* *}$ & $0.32^{* * *}$ & 0.07 & $0.5^{* * *}$ & 0.4 \\
\hline Change in Call Prices & $-9.07 \times 10^{-5}$ & -0.02 & 0.35 & 0.03 & 0.02 & -0.16 & -0.43 \\
\hline Put Price & $-0.15^{* *}$ & $-0.19^{* *}$ & $-1.16^{* * *}$ & $-0.30^{* * *}$ & -0.06 & $-0.5^{* * *}$ & -0.70 \\
\hline Change in Put Prices & -0.02 & $-0.11^{* *}$ & $2.05^{* * *}$ & 0.20 & 0.01 & 0.27 & -0.26 \\
\hline $\begin{array}{l}\text { Canadian Dollar-US } \\
\text { Dollar Exchange Rate }\end{array}$ & $-0.26^{* * *}$ & $-0.29^{* * *}$ & $-0.47^{* *}$ & -0.33 & -0.27 & $-0.29^{* * *}$ & 0.00 \\
\hline Supply of Oil & $-4.81 \times 10^{-3^{* * *}}$ & $-4.12 \times 10^{-3^{* * *}}$ & $-1.39 \times 10^{-3^{* * *}}$ & $-3.0 \times 10^{-3^{* * *}}$ & $-2.8 \times 10^{-3^{* * *}}$ & $-3.13 \times 10^{-3^{* * *}}$ & $-5.9 \times 10^{-3 * * *}$ \\
\hline News of Oil Prices & -0.03 & -0.03 & $-0.33^{* * *}$ & $-0.09^{* * *}$ & $-0.078^{* * *}$ & $-0.091^{* * *}$ & $-0.4^{* * *}$ \\
\hline $\mathrm{N}$ & 688 & 825 & 879 & 899 & 889 & 873 & 868 \\
\hline $\mathrm{R}^{2}$ & 0.99 & 0.99 & 0.97 & 0.99 & 0.99 & 0.99 & 0.98 \\
\hline
\end{tabular}

Table 1. Results of OLS regressions of oil futures prices on options with 1 - 7 month maturities.

${ }^{*} p<0.05,{ }^{* *} p<0.01,{ }^{* * *} p<0.001$. 
Table 2. Results of ordinary least squares regressions of call option prices and put option prices on oil futures prices for 1-month, 2-month, and 4-month options.

\begin{tabular}{ccccccc}
\hline Variable & 1-Month Calls & 1-Month Puts & 2-Month Calls & 2-Month Puts & 4-Month Calls & 4-Month Puts \\
\hline Constant & $55.64^{* * *}$ & $73.58^{* * *}$ & $44.47^{* * *}$ & $59.41^{* * *}$ & $89.36^{* * *}$ & $93.96^{* *}$ \\
Oil Futures Price & $0.05^{* *}$ & $0.07^{* *}$ & 0.02 & 0.05 & $0.03^{* *}$ & $0.04^{* * *}$ \\
Call Price & & $-0.95^{* * *}$ & & $-0.89^{* * *}$ & $-0.95^{* * *}$ \\
Put Price & $-0.56^{* * *}$ & & $-0.38^{* * *}$ & & $-0.89^{* * *}$ & \\
Canadian Dollar-US & -0.02 & -0.03 & 0.01 & 0.04 & $0.05^{* * *}$ & $0.04^{* * *}$ \\
Dollar Exchange Rate & $-6.31 \times 10^{-4^{* * * *}}$ & $-8.32 \times 10^{-4^{* * *}}$ & $-4.73 \times 10^{-4^{* * *}}$ & $-6.42 \times 10^{-4^{* * *}}$ & $-9.42 \times 10^{-4^{* * *}}$ & $-9.9 \times 10^{-4^{* * *}}$ \\
Supply of Oil & 0.01 & -0.01 & 0.006 & 0.006 & 0.009 & $0.01^{*}$ \\
News of Oil Prices & 689 & 689 & 826 & 826 & 894 & 894 \\
$\mathrm{~N}$ & 0.75 & 0.79 & 0.80 & 0.76 & 0.97 & 0.98 \\
$\mathrm{R}^{2}$ & & & & & \\
\hline
\end{tabular}

${ }^{*} p<0.05, \stackrel{* *}{p} p<0.01, \stackrel{* * *}{p} p<0.001$.

meaningful given the monotonic increase in price of oil from 1971-2014. The sudden reversal of prices merits the theoretical and empirical assessment that this paper has provided. In addition to the decrease in oil prices in the long-term from news about future oil prices and in the short-term about the weakening of the Canadian dollar to the US dollar, we envision a role for call option sellers to reduce prices with a modest level of speculation and put buyers to reduce oil prices to a local minimum with substantial amounts of speculative trading. Theoretically, the popular press perceives the futures price of oil as a function of oversupply of production as follows.

$$
F=O S
$$

This paper expands the above relationship to include additional variables.

$$
O F=\alpha+C P+P P+C A D+O S+N O
$$

where

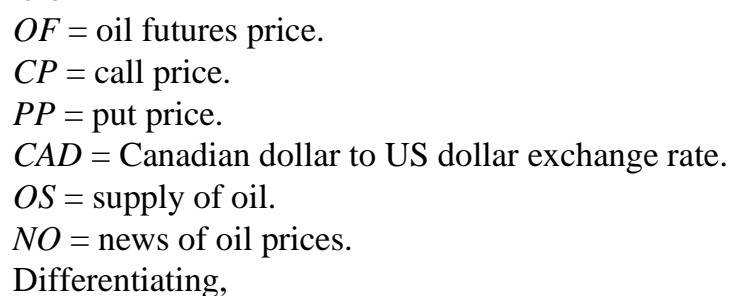

$$
d / d x(O F)=d / d x(C P)+d / d x(P P)+d / d x(C A D)+d / d x(O S)+d / d x(N O)
$$

The principal determinant is $O S$, followed by $C A D$ in the short-term and $N O$ in the long-term. Call sellers reduce oil futures prices slightly as they collect diminishing amounts of call premiums in each successive round of trading, finally exiting the market when no further calls are purchased as call buyers realize that oil futures prices will continue to fall eliminating their likelihood of ever profiting from price increases. Put buyers reduce oil futures prices substantially as they earn higher profits as prices fall with sales at higher prices than the market in each round. However, as they benefit from these sales at higher prices, the puts become more expensive, so that they finally stop trading when the gain from put purchase is exactly equal to the loss from high put purchase prices, or the Gain $=X$, strike price of the put option $-F$, oil futures price $=P P$, put price.

At this point, $d^{2} x / d x^{2}(P P)=0$ or a local maximum is achieved.

Our results support [7]'s model of multimarket trading to the extent that traders in the futures market observe demand for reduced oil prices in the options market and adjust their own prices. [7] established the existence of such linked trading between the stock market and the options market. This paper provides evidence of it in the options market and the futures market as well. Informed traders choose to capitalize on profit-making opportunities in more than one market. 


\section{References}

[1] Hughes, J.E., Kittel, C.R. and Sperling, D. (2008) Evidence of a Shift in the Short-Run Price Elasticity of Gasoline Demand. The Energy Journal, 29, 93-114. http://dx.doi.org/10.5547/ISSN0195-6574-EJ-Vol29-No1-9

[2] Latane, H.A. and Rendleman, R.H. (1976) Standard Deviation of Stock Price Ratios Implied in Option Prices. Journal of Finance, 31, 369-381. http://dx.doi.org/10.1111/j.1540-6261.1976.tb01892.x

[3] Stoll, H. and Whaley, R.E. (1986) New Option Linkages: Arbitrageable Linkages and Valuation. Advances in Futures and Options Research, 1A, 25-62.

[4] Overdahl, J.A. and Matthews, H.L. (1988) The Use of NYMEX Options to Forecast Crude Oil Prices. The Energy Journal, 9, 135-147. http://dx.doi.org/10.5547/ISSN0195-6574-EJ-Vol9-No4-7

[5] Whaley, R.E. (1986) Valuation of American Futures Options: Theory and Empirical Tests. Journal of Finance, 41, 127-150. http://dx.doi.org/10.1111/j.1540-6261.1986.tb04495.x

[6] Easley, D.O., O’ Hara, M.H. and Srinivas, P.S. (1998) Option Volume and Stock Prices: Evidence on Where Informed Traders Trade. Journal of Finance, 53, 431-465. http://dx.doi.org/10.1111/0022-1082.194060

[7] Abraham, R., Harrington, C.W. and Williams, A.A. (2011) Multimarket Trading at Merger Announcement and Completion. Journal of Derivatives and Hedge Funds, 17, 186-197. http://dx.doi.org/10.1057/jdhf.2011.13

[8] Abraham, R. and Harrington, C.W. (2013) Predicting Informed Trading at Merger Announcements. Journal of Economic Studies, 40, 658-670. http://dx.doi.org/10.1108/JES-02-2012-0021

[9] Zikiye, M., Abraham, R. and Harrington, C.W. (2014) Trading Responses to Negative Signals. Theoretical Economics Letters, 4, 378-385. http://dx.doi.org/10.4236/tel.2014.46049

[10] Davig, T., Melek, N.C., Nie, J., Smith, A.L. and Tuzeman, D. (2015) Evaluating a Year of Oil Price Volatility. Federal Reserve Bank of Kansas City Economic Review, Third Quarter, 5-30.

[11] Baumeister, C. and Kilian, L. (2015) Understanding the Decline in the Price of Oil since June 2014. CFS Working Paper, No. 501.

[12] Akram, Q.F. (2004) Oil Prices and Exchange Rates: Norwegian Evidence. The Econometrics Journal, 7, 476-504. http://dx.doi.org/10.1111/j.1368-423X.2004.00140.x

[13] Brown, KA. (2015) How \& Why Oil Impacts the Canadian Dollar (CAD). http://www.investopedia.com/articles/investing/021315/how-why-oil-impacts-canadian-dollar-cad.asp

[14] Nisbet, R. and Ross, L. (1980) Human Inference: Strategies and Shortcomings of Social Judgement. Prentice-Hall, Englewood Cliffs.

[15] Abraham, R. and Harrington, C.W. (2016) Predictors of Positive Earnings Surprises. Open Journal of Accounting, 5, 25-34. http://dx.doi.org/10.4236/ojacct.2016.53004

[16] Fischer, D. (2012) Investor Underreaction to Earnings Surprises and Overreaction to Product News in the Drug Industry. Journal of Business and Economic Studies, 18, 82-90.

\section{Submit or recommend next manuscript to SCIRP and we will provide best service for you:}

Accepting pre-submission inquiries through Email, Facebook, LinkedIn, Twitter, etc.

A wide selection of journals (inclusive of 9 subjects, more than 200 journals)

Providing 24-hour high-quality service

User-friendly online submission system

Fair and swift peer-review system

Efficient typesetting and proofreading procedure

Display of the result of downloads and visits, as well as the number of cited articles

Maximum dissemination of your research work

Submit your manuscript at: http://papersubmission.scirp.org/ 